\title{
The Contents of Environmental Education in Current Elementary Social Studies Textbooks in China
}

\author{
Weiju Zhao ${ }^{1}$, Ling Liu ${ }^{2}$, Di Wang ${ }^{3}$ \\ ${ }^{1,2}$ College of Education Science, Nantong University, China \\ ${ }^{3}$ Dinghuo Elementary School, Yangzhou city, China
}

\begin{abstract}
The textbooks, step by step, unfold from the "small" environment to "big" environment, from concrete to abstract and from the things around us to the earth we live in. The contents are gradually expanded in an orderly way. Evidently, there are a few defects which claim our attention. The environmental education is incoherent as the contents of environmental education almost appear in the second semester.
\end{abstract}

Keywords: Environmental Education, Textbooks, Moral Education, People's Education Press

\section{INTRODUCTION}

The UNESCO defined environmental education as a process of cognizing values and clarifying concepts, which aims at developing the critical skills and attitudes of knowing and appraising human beings and other cultural environment and ecological environment, prompting folks to make correct decisions on environmental problems and forming the code of conduct that is relevant to environmental quality (Joy, 2002). From the international point of view, environmental education has become a part of Education. In China, environmental protection has been listed as a basic state policy since the 18th CPC National Congress and The Curriculum Reform of Basic Education explicitly demonstrates cultivating students with preliminary humanistic and environmental awareness as the teaching aim of the new course. Therefore, educators must attach great importance to fostering pupils' awareness of environmental protection and good habits. The advancement and reformation of environmental education can be reflected in the textbooks, also researching textbooks can have an insight into the implementation of environmental education (Sun, 2015). The textbooks of Moral Education by People's Education Press are the effective carrier of environmental education for pupils. Only when the contents of environmental education in the textbooks are completely exploited can teachers creatively guide pupils to raise environmental protection awareness. Hence, it is significant to analyze the contents of environmental education in textbooks.

\section{METHOD}

We select 12 textbooks of Moral Education (ME), "Morality and Life" (Grades 1 and 2) and "Morality and Society" (Grades 3, 4, 5 and 6), by People's Education Press of China as research objectives. Through textual analysis, including illustrations and contents, we have found 5 thematic units are connected with environmental education. The 5 thematic units are respectively distributed in 5 textbooks, the second semester in Grade1 and Grade2, the first semester in Grade 4, the second semester in Grade5 and Grade 6, which are the main analysis objectives.

\section{RESUlTS AND DISCUSSION}

Each textbook has 4 thematic units and each unit has 3-4 relevant subordinated themes that still have several smaller topics. By the "thematic unit" mode of presentation, pupils can understand the environment from multi-angles, which is conducive for pupils to form the environmental cognition and awareness.

\subsection{Themes}

The contents of environmental education in the primary school ME textbooks are mainly designed in 5 themes: "Walking into nature", "Making our home better", "Cherishing the life", "The earth we live 
in" and "The home of human beings". These themes are further divided into three levels: (a) understanding the environment: the aim of "Walking into nature" and "Cherishing the life" is to enable students to experience the beauty of nature, to learn about the surrounding environment and to understand the value of life so as to inspire students to love the nature; (b) feeling the environment: the focus of "Making our home better" is to make pupils feel their own living environment and fully understand that the various environmental crises our earth is currently facing and consequently alert students to the urgent need to protect the environment; (c) protecting the environment: "We live in the earth" and "The home of human beings" mainly teach students to protect the environment and help students get into the habit of protecting the environment.

In addition, there are some subordinated themes which, more or less, also involve the contents of environmental education. For instance, "Making our classroom clean and beautiful" of the first semester in Unit 1 Grade 2 admonishes pupils to keep classroom clean and tidy; "Where is the autumn" of the first semester in Unit 2 Grade 2 describes a gorgeous picture for pupils to feel and experience, motivating their affection towards the environment.

\subsection{Contents}

Through the analysis of the 12 textbooks, we find that not every book is related to the content of environmental education. We list the content as follows.

Table1.

\begin{tabular}{|c|c|c|c|}
\hline Grade & Unit Theme & Subordinated Theme & Thematic Content \\
\hline \multirow{2}{*}{$\begin{array}{l}\text { Grade } 1 \\
\text { (second } \\
\text { semester) }\end{array}$} & \multirow[b]{2}{*}{ Walking into nature } & Spring is coming & Understand the main features of spring \\
\hline & & Playng games with the sun & Feel the warmth of spring, close to nature \\
\hline \multirow{4}{*}{$\begin{array}{l}\text { Grade } 2 \\
(\text { second } \\
\text { semester })\end{array}$} & \multirow{4}{*}{$\begin{array}{l}\text { Making our home } \\
\text { better }\end{array}$} & Our mother earth & $\begin{array}{l}\text { Understand the relationship between } \\
\text { animals and plants and human beings }\end{array}$ \\
\hline & & Beautifying our home & $\begin{array}{l}\text { Learn to do whatever they can to protect } \\
\text { the environment, make the waste } \\
\text { profitable }\end{array}$ \\
\hline & & Flowers and trees nod and laugh & $\begin{array}{l}\text { Take care of flowers and trees with } \\
\text { practical action }\end{array}$ \\
\hline & & Making friends with animals & $\begin{array}{l}\text { Learn to live in harmony with animals, } \\
\text { realize that caring about animals is caring } \\
\text { about human beings }\end{array}$ \\
\hline \begin{tabular}{|l|} 
Grade 4 \\
(first \\
semester)
\end{tabular} & Cherishing the life & Beautiful lives & $\begin{array}{l}\text { Love flowers and trees, care for animals } \\
\text { and plants }\end{array}$ \\
\hline $\begin{array}{l}\text { Grade } 5 \\
\text { (second } \\
\text { semester) }\end{array}$ & The earth we live in & Our global village & $\begin{array}{l}\text { Feel the beauty and magic of the earth, love } \\
\text { and protect the Earth }\end{array}$ \\
\hline \multirow[b]{2}{*}{$\begin{array}{l}\text { Grade } 6 \\
\text { (second } \\
\text { semester) }\end{array}$} & \multirow[b]{2}{*}{$\begin{array}{l}\text { The home of human } \\
\text { beings }\end{array}$} & Only one earth & Cherish the resources and protect the earth \\
\hline & & What can we do for the earth & $\begin{array}{l}\text { By reducing the consumption of } \\
\text { resources, actively participate in the } \\
\text { construction of beautiful environment and } \\
\text { other ways to retain the green of the earth }\end{array}$ \\
\hline
\end{tabular}

The contents of the environmental education in the current textbooks involve a number of aspects. For low-grade pupils, the ME textbooks primarily introduce environmental knowledge, including animals, plants, natural resources and so on. From the micro level to the macro level, these contents not only entitle pupils to feel the concrete "environment", but also let them recognize that the "environment" is around us, which contributes to helping students initially form the environmental awareness. For middle-grade pupils, the textbooks illustrate the fundamental knowledge of protecting our surroundings, guiding pupils to develop the habits of environmental protection in their daily life. For high-grade pupils, the textbooks turn to describing the environment of human existence. The text reveals everyone is a member of our common home, therefore, the environmental construction needs all individuals' participation and endeavors. 


\subsection{Compiling}

The editors of the textbooks compile the environmental themes in sequence as follow: knowing nature, close to nature, feeling the beauty of nature, raising environmental awareness.

For low-grade pupils, the key point is to help pupils form the concept of environment. For middle-grade pupils, the focus is life. Pupils can understand life, feel the magic of life, cherish life, and value the environment. For high-grade pupils, the focus of the textbooks is on the earth. Pupils are expected to understand our living environment from a macro perspective, especially to understand the earth is being damaged and realize the adverse impact subsequently.

The textbooks, step by step, unfold from the "small" environment to the "big" environment, from concrete to abstract and from the things around us to the earth we live in. The contents are gradually expanded, in accordance with the law of children's cognitive development. The layout of textbooks is in accordance with children's physical and psychological development features. The emphasis of the presentation and design of the "environment" content proceeds in an orderly way. Although some contents overlap, they have different emphasis, which inspires pupils to observe the earth and the environment from multi-angles. However, the textbooks also present a few problems. For example, pupils' understanding and protecting the environment is not accomplished overnight, but is a continuous activity. Obviously, the contents of environmental education element almost appear in the second semester. In addition, the third grade textbook does not involve the "environment", which is not conducive to pupils' coherent study.

\subsection{Column}

Table2.

\begin{tabular}{|c|c|c|}
\hline Subordinated Theme & Main Column Types & Column Content \\
\hline Spring is coming & Understand, feel & $\begin{array}{l}\text { Look for spring } \\
\text { Praise spring }\end{array}$ \\
\hline Playing games with the sun & Understand, feel & $\begin{array}{l}\text { Wonderful light and shadow } \\
\text { Beautiful rainbows }\end{array}$ \\
\hline Our mother earth & Understand, feel, survey & $\begin{array}{c}\text { Mother earth raises us } \\
\text { Mother earth crying } \\
\text { How our surroundings look like }\end{array}$ \\
\hline Beautifying our home & Understand, handmade & $\begin{array}{l}\text { Find a house for rubbish } \\
\text { Reuse waste materials }\end{array}$ \\
\hline $\begin{array}{l}\text { Flowers and trees nod and } \\
\text { laugh }\end{array}$ & Understand, say & $\begin{array}{c}\text { Forest party } \\
\text { Plants all have great abilities } \\
\text { I am a little green guardian }\end{array}$ \\
\hline Making friends with animals & Understand, draw & $\begin{array}{l}\text { I love animals } \\
\text { The story of MingMing and birds } \\
\text { Mother Giraffe confides }\end{array}$ \\
\hline Beautiful lives & Understand, think, say & $\begin{array}{c}\text { Life makes the world beautiful } \\
\text { They also need love }\end{array}$ \\
\hline Our global village & Understand, handmade & $\begin{array}{l}\text { Look at the contractible world --Globe } \\
\text { Longitude, latitude and equator Continents and } \\
\text { oceans } \\
\text { The beautiful global village } \\
\text { The countries in the world }\end{array}$ \\
\hline Only one earth & $\begin{array}{l}\text { Understand, dialogue, } \\
\text { survey }\end{array}$ & $\begin{array}{c}\text { The dedication of the earth } \\
\text { Our only home } \\
\text { The burden of the earth } \\
\text { The environment of our hometown }\end{array}$ \\
\hline What can we do for the earth & $\begin{array}{l}\text { Understand, survey, } \\
\text { handmade }\end{array}$ & $\begin{array}{c}\text { Our living environment } \\
\text { Retain the green of the nature } \\
\text { Create a water-saving society } \\
\text { Reduce waste pollution }\end{array}$ \\
\hline
\end{tabular}


From the above table, we can see that the compilers mostly adopt knowledge-based and observation materials. While the textbooks for high-grade pupils add several short surveys and handcraft because only mastering the knowledge is not enough. For 5th and 6th grade pupils, it's more significant to carry out a few practical investigations that are constructive and meaningful to environment protection. For example, the textbooks definitively state that we should not leave garbage everywhere, sort the rubbish out, do not waste, recycle waste materials, plant trees and flowers as well as take care of them, which is simple and convenient for pupils to practice. Besides, the short researches like "How our surroundings look like" and "The deterioration of our hometown" are necessary for pupils to participate in the environmental protection action. At the same time, pupils may strength their comprehension of the environment and avail themselves of this process to achieve the capabilities of cooperation, communication, delving and pondering. The "Think, Dialogue and Say" column is aim to cultivating pupils' ability of environmental thinking.

\subsection{Illustrations}

The prominent trait of these textbooks is the imaginative illustrations and their accompanying text. Overall, the pictures consist of cartoon pictures, children's real-life pictures and referenced pictures from other materials. The images with content-orientated concentration and more explicit meaning are both ornamental and readable.

\subsubsection{Cartoon Pictures}

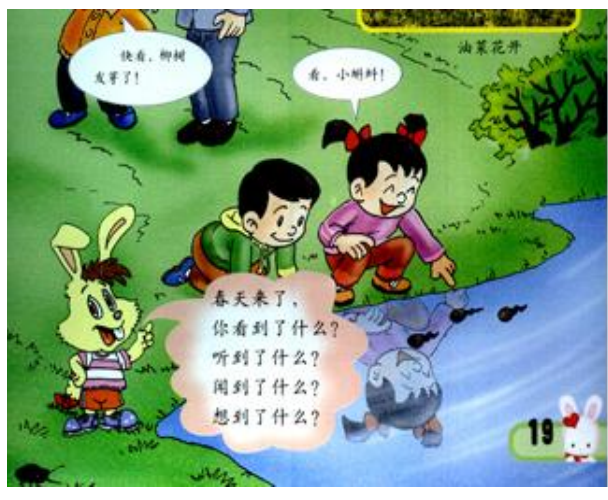

Picture1

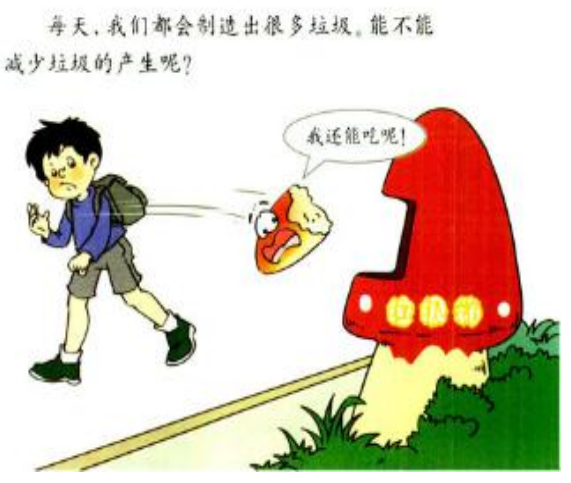

Picture2

Pictures 1 and 2 are the most common cartoon pictures utilized in ME textbooks. Pupils, especially those of low-grades, are prone to be fascinated by cartoon characters that are vivid and quickly narrow the distance between pupils and other creatures. Cartoon pictures, in line with the characteristics of pupils, personify abstract figures and are conducive for pupils to understand the main ideas of the textbooks. For instance, picture 1 encourages pupils to experience and explore the characteristics of spring. Picture 2 counsels pupils not to waste food.

\subsubsection{Real-Life Pictures}

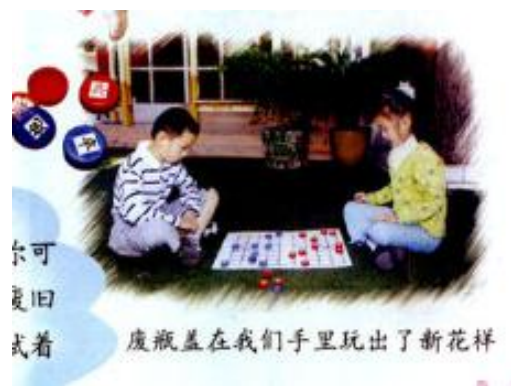

Picture3

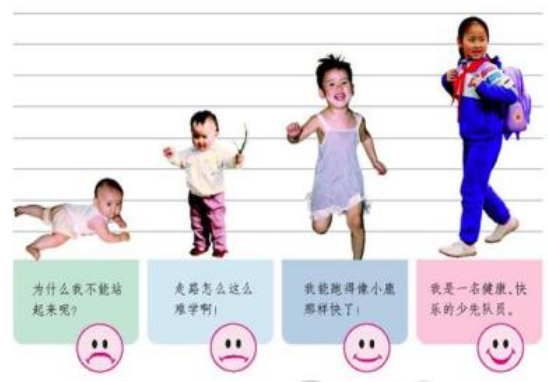

Picture4

Pictures 3 and 4 are real-life photos, reflecting pupils' the daily life experiences. Life is not conceptual, ideal and virtual and children can feel and experience in real life. Compared with the cartoon pictures, these pictures are more realistic. When pupils see these photos, they will immediately introspect themselves. Hence, the corresponding photos make pupils realize their 
inappropriate behaviors as well as set a good example for them. As picture 3 shows that the waste bottle cap can be utilized as a chess. Picture 4 illustrates the different feelings in the process of life growth.

\subsubsection{Referenced Pictures}

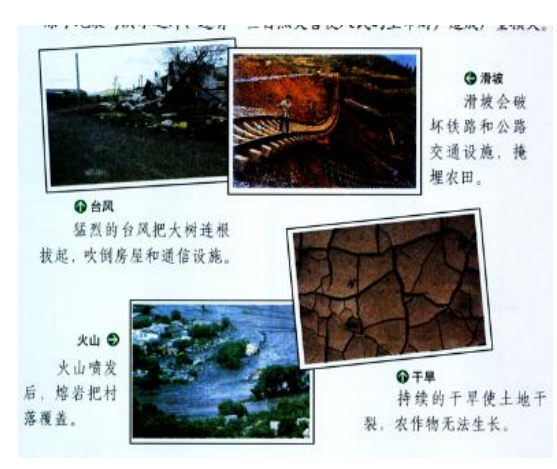

Picture5

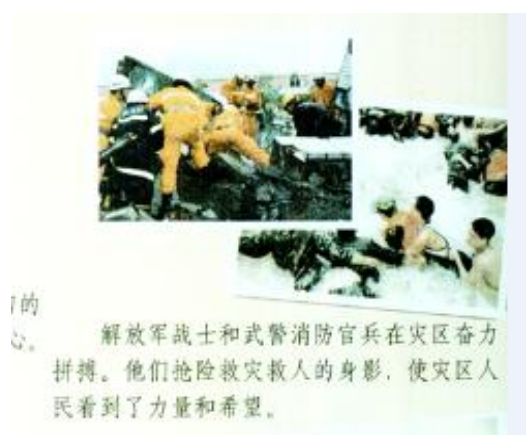

Picture6

Pictures 5 and 6 are referenced pictures from other materials. As pupils' experiences are limited and most of the pupils have not encountered natural disasters or environmental destruction, the reference pictures seem particularly important. They can make up for the lack of pupils' experiences and stimulate them to fully understand the real situation of the environment and the earth. Especially for low-grade pupils who are still in the stage of imaginative thinking, these images can enrich and deepen their sensory feelings, so as to help students establish a correct concept of the environment.

\section{Conclusion}

The textbooks of ME containing environmental education materials present certain environmental information, assisting pupils to learn about the composition of the ecological environment and the relationship between humans and nature, so that pupils may build up their environmental awareness and values and participate in dealing with environmental and developmental issues and actions. The design of arranging the contents in different columns develops pupils' capacity of thinking and performing and the various illustrations enrich pupils' environmental perspectives. The textbooks, step by step, unfold from the "small" environment to the "big" environment, from concrete to abstract and from the things around us to the earth we live in. The contents are gradually expanded in an orderly way. Although some contents overlap, they have different emphasis, which inspires pupils to observe the earth and the environment from multi-angles. Evidently, there are a few defects which claim our attention. The environmental education is incoherent in that the contents of environmental education almost appear in the second semester. Besides, the third grade textbook does not involve the contents of environmental education.

\section{ACKNOWLEDGEMENT}

The Key Project from Chinese National Education Science of the 12th Five-years Plan "Research on comparing current elementary social studies textbooks in China and Australia", approval number: DEA120200.

\section{REFERENCES}

[1] Joy, A. (2002). The Environmental Education of 21st Century: Theory, Practice, Process and Prospect. Beijing: China Light Industry Press.

[2] Ministry of Education of the People's Republic of China. (2001). The Curriculum Reform of Basic Education [EB/OL]. Retrieved from http://www.moe.edu.cn/publicfiles/business/htmlfiles/ moe/moe_309/200412/4672.html

[3] Yu, S. (2015). The Reflection of Environmental Education in Science Textbook: A Comparative Study on Textbooks of the Chinese Mainland and Taiwan (Unpublished master's thesis). East China Normal University, Shanghai. 


\section{AUTHORS' BIOGRAPHY}

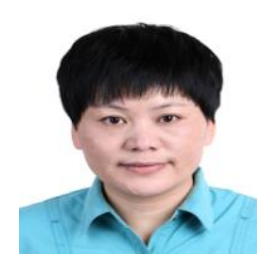

Weiju Zhao, is an associate professor of education in the College of Education Science at Nantong University. She is interested in elementary school education and moral education and can be reached by email at ntzhwj@126.com

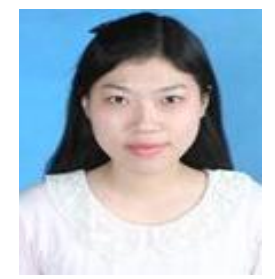

Ling Liu, is a graduate student in College of Education Science at Nantong University. Her major is elementary school education and can be reached by email at505326973@qq.com

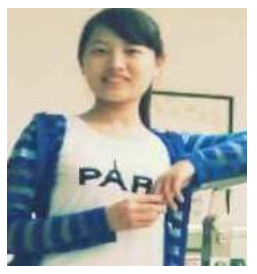

Di Wang, is a teacher of Yangzhou Dinghuo primary school. She is interested in elementary school education and can be reached by email at $876972466 @ q q . c o m$ 